Document downloaded from:

http://hdl.handle.net/10251/79098

This paper must be cited as:

García Ballesteros, S.; Mora Carbonell, M.; Vicente Candela, R.; Sabater Marco, C.; Castillo López, MÁ.; Arques Sanz, A.; Amat Payá, AM. (2016). Gaining further insight into photoFenton treatment of phenolic compounds commonly found in food processing industry. Chemical Engineering Journal. 288:126-136. doi:10.1016/j.cej.2015.11.031.

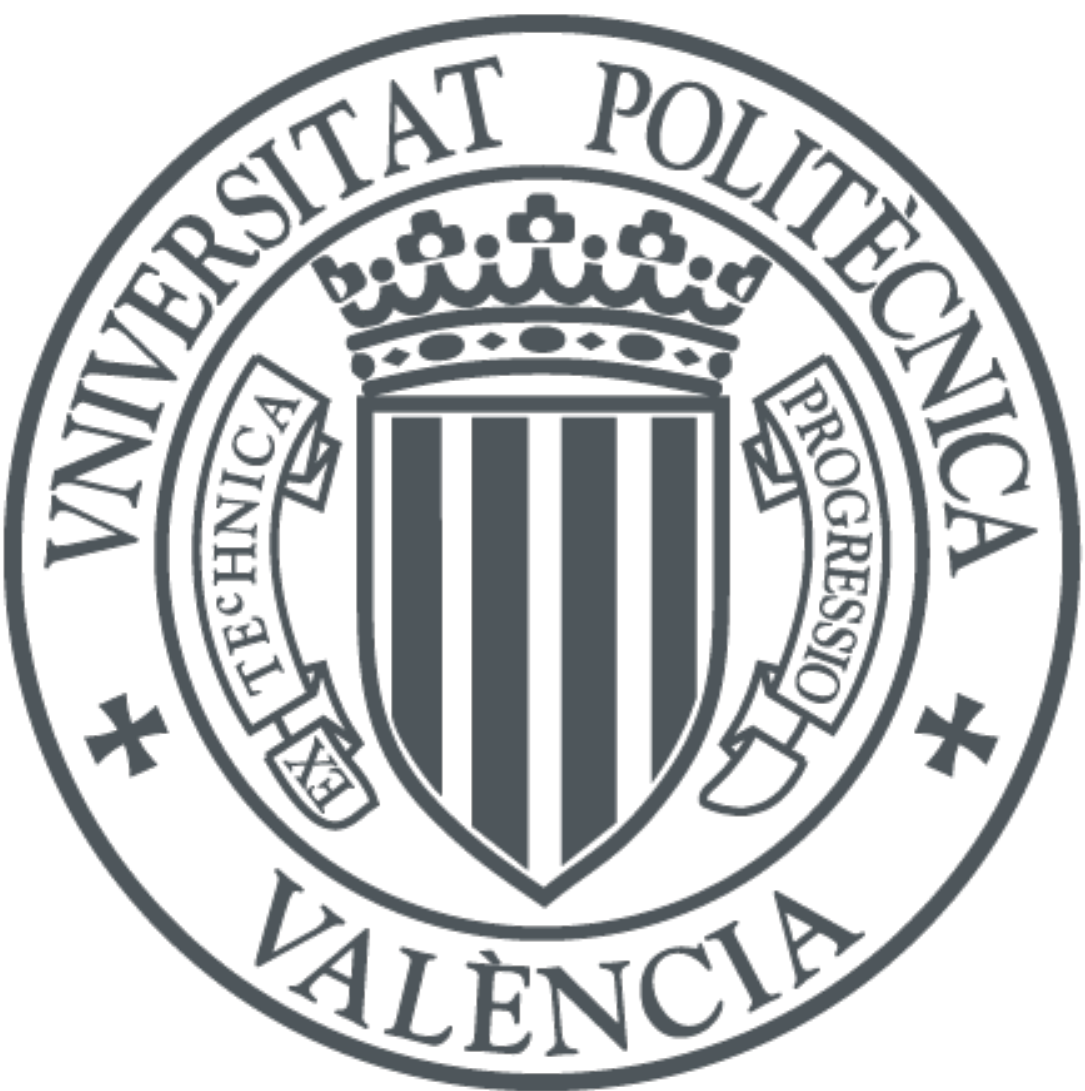

The final publication is available at

Copyright Elsevier

Additional Information 


\title{
Gaining further insight into photo-Fenton treatment of phenolic compounds commonly found in food processing industry
}

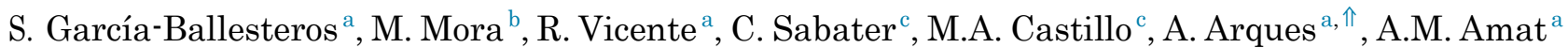

Keywords:

Photo-Fenton

Phenolic compounds

Doehlert matrixes

Toxicity

Excitation emission matrix fluorimetry

\section{a b s t r a c t}

A mixture of eight phenolic compounds, namely 2,4-dinitrophenol, tannic, ellagic, gallic, protocatechuic, vanillic, syringic and sinapic acids, have been treated by means of a photo-Fenton process under simulated and real sunlight. An experimental design methodology, based in Doehlert matrixes, was employed to check the effect of the concentration of $\mathrm{Fe}(\mathrm{II})$ and $\mathrm{H} O$ as well as $\mathrm{pH}$. Response surfaces show that photo-Fenton can be extended to $\mathrm{pH}$ values clearly above 2.8 , probably due to complexation of iron with the phenolic substances. Experiments performed under solar irradiation at $\mathrm{pH}=3.9$ showed that complete removal of the monitored pollutants was achieved in less than $3 \mathrm{~min}$; mineralisation was also efficient, although some organics remained in the solution. Toxicity was monitored according to Pseudokirchneriella subcapitata and Daphnia magna bioassays; Recombinant Yeast Assay (RYA) was employed to assess estrogenic and dioxin-like activities. 2,4-Dinitrophenol was demonstrated to be the major concern and, in general, photo-Fenton resulted in a detoxification of the solution. Finally, excitation emission matrix (EEM) fluorimetry was employed to obtain complementary information on the behaviour of organic matter. Most peaks associated with the parent pollutants disappeared after short irradiation periods and, at $12 \mathrm{~min}$ of irradiation chromophores were destroyed, what can be associated with the removal of complex molecules.

(C) 2015 Elsevier B.V. All rights reserved.

\section{Introduction}

Aqueous wastes from food processing industry, such wine, olive oil or coffee production, canning industry or cork stew, represent an important environmental concern. They show a complex composition including mineral salts, sugars, biological macromolecules, fatty acids, tannins, phenols or polyphenols at variable concentrations. In particular, phenols and related compounds such tannins are difficult to treat by classical means as they are reluctant to biodegradation or even toxic, thus inhibiting the removal of the biodegradable fraction $[1,2]$. 

Advanced oxidation processes (AOPs) have been demonstrated as promising alternatives to deal with phenolic compounds; these technologies involve the in situ generation of highly reactive species via chemical, thermal or photochemical pathways [3]. Several studies have been published showing the ability of AOPs to remove those compounds from synthetic model solutions [4,5], but also from real effluents [6-10]. Interestingly, AOPs exhibit some selectivity for phenolic compounds vs. other more degradable organics, as observed in paper mill effluents [11,12]; this is an important advantage, as combination of $\mathrm{AOP}$ as a pre-treatment to remove the non-biocompatible fraction with biological processes is a meaningful strategy for food industry effluents $[13,14]$.

The use of sunlight in photochemical AOPs represent an enhanced sustainability for those treatments. Photo-Fenton, one of the processes that can be driven under solar irradiation, is based on the ability of iron salts to catalyse decomposition of hydrogen peroxide to generate reactive species, such as hydroxyl radical [15]; this process is $\mathrm{pH}$-dependent being the optimum value ca. 2.8. Results have been published dealing with the use of photoFenton in the treatment of phenolic compounds or real food processing industry effluents $[14,16]$. Briefly, the mechanism of oxidation of this family of compounds by hydroxyl radicals involves further hydroxylation of the aromatic ring, formation of quinones and, finally, cleavage of the aromatic ring to form carboxylic compounds, as described for nitrophenols [9]. However, some important issues still deserve further research. For instance, being elimination of the toxicity mainly associated to phenols one of the goals of the photo-oxidative treatment, it is interesting to assess detoxification according to different methods, as these results vary depending on the species that is employed [17]. Furthermore, monitoring the endocrine disrupting behaviour of those substances throughout the process seems a meaningful step forward, as this effect is not detected by classical toxicity bioassays [18].

Another issue that deserves further research is the role of $\mathrm{pH}$ in complex effluents. It is well known that substances able to modify the coordination sphere of iron may change the optimum $\mathrm{pH}$ for photo-Fenton $[19,20]$. In fact, it has been recently reported that the photo-Fenton treatment of olive oil mill wastewater can be applied at $\mathrm{pH}=5$ with only a slight change in efficiency when compared with 2.8 [6]. This result is interesting, as the costs associated to $\mathrm{pH}$ modification might be reduced. Also regarding with the behaviour of complex systems, applying new techniques to gain further insight into changes in their composition seems meaningful. In this context, excitation emission matrix (EEM) fluorimetry might be a useful tool. It has been commonly used in the characterisation dissolved organic matter [21,22], although the use of EEM has been recently extended to other fields [23]. Hence, it is interesting to check if EEM can provide useful information on the behaviour of phenolic compounds submitted to AOPs, as a previous step before developing tools for a mathematical modelling of the process.

In order to investigate the issues above described, a mixture of eight phenolic substances commonly found in food processing effluents has been submitted to a photo-Fenton process under simulated and real sunlight. This approach has already been used for other type of chemicals (e.g. pesticides or pharmaceuticals) and it has been demonstrated to provide useful information as the system is not so complex as real effluents (its composition is well determined and constant) but, it is not as simple as a single model compound and hence, more representative of the phenolic fraction $[24,25]$. The mixture consisted of tannic acid as example of tannins, ellagic acid as an example of a polyphenol, 2,4-dinitrophenol, and five phenolic acids with different substitution, namely gallic, protocatechuic, vanillic, syringic and sinapic acids (see Fig. 1 for structures). An experimental design methodology based on Doehlert matrixes has been employed to determine the effect of $\mathrm{pH}, \mathrm{H}_{2} \mathrm{O}_{2}$ amount and iron concentration; the Doehlert design has been commonly employed as a chemometric tool, enabling to minimise the number of experiments required to obtain the equations that predicts the behaviour of the system in the studied region [26]. In addition to pollutants concentration, EEM have been used to provide complementary information on the process. Finally, two types of bioassays have been applied to assess the environmental risks associated with the pollutants and the treated mixture: (1) toxicity assays with the algae Pseudokirchneriella subcapitata and the crustacean Daphnia magna, according to their respective guidelines and (2) Recombinant Yeast Assay (RYA) to assess estrogenic and dioxin-like activities. RYA uses two genetically modified yeasts: ER-RYA system that contains the human estrogenic hormone receptor, and AhR-RYA system that expresses human aryl hydrocarbon receptor. Both strains contain a reporter plasmid expressing the Escherichia coli enzyme b-galactosidase. This enzyme will only be expressed in the presence of the receptor-ligand complex. The expression of gen is easy to follow using convenient enzyme substrates [27].

\section{Experimental}

\subsection{Reagents}

Tannic acid, ellagic acid, 2,4-dinitrophenol, gallic acid, protocatechuic acid, vanillic acid, syringic acid and sinapic acid were purchased from Sigma-Aldrich and used as received. Hydrogen peroxide (30\% v/v) and ferrous sulphate were supplied by Panreac. Water employed in the experiments was Milli-Q grade.

The alga P. subcapitata and dormant eggs of crustacean D. magna were supplied by ECOtest S.L. (Valencia, Spain). The recombinant strains of Saccharomyces cerevisiae (BY4741 strain (ER strain) and YCM4 strain (AhR strain)) capable to detect estrogenic and aryl hydrocarbon receptor (AhR) agonist activities, respectively, were kindly provided by Dr. Benjamin Piña from Institute of Environmental Assessment and Water Research (IDAEA-CSIC), Barcelona, Spain. All medium constituents were supplied by Difco (Basel, Switzerland). Prototrophic markers, standards (17-b-estradiol (E2) and b-naphthoflavone (b-NF)) and enzymatic substrate (4methylumbelliferone b-o-galactopyranoside and bmercaptoethanol) were supplemented by Sigma-Aldrich. Assay buffer (Triton X-100) and Y-PER (Yeast Protein Extraction Reagent) were supplied by Fisher Chemical and Thermo Scientific, respectively.

\subsection{Reactions}

Laboratory scale experiments were carried out in cylindrical Pyrex vessels ( $55 \mathrm{~mm}$ internal diameter). A solar simulator (Sun 2000, ABET Technologies) equipped with a $550 \mathrm{~W}$ Xenon Short Arc Lamp was used as irradiation source; a glass filter was used to cut off the small fraction of radiation with $\mathrm{k}<300 \mathrm{~nm}$. For each experiment, the reactor was loaded with $250 \mathrm{~mL}$ of solution containing the mixture of all eight pollutants $(1 \mathrm{mg} / \mathrm{L}$ of each). Iron (II) was added as sulphate salt, with an initial concentration in the range $1-5 \mathrm{mg} / \mathrm{L}$. The $\mathrm{pH}$ was adjusted by dropwise addition of diluted sulphuric acid or, eventually, sodium hydroxide. Then, hydrogen peroxide was added with an initial amount that ranged from $13.8 \mathrm{mg} / \mathrm{L}$ until $96.7 \mathrm{mg} / \mathrm{L}$ (corresponding, respectively, to $1 / 4$ and $7 / 4$ of the stoichiometric amount of $\mathrm{H}_{2} \mathrm{O}_{2}$ required to oxidise completely all the pollutants). Samples were periodically taken to be analysed.

Eventually, reactions were scaled up in a solar photoreactor Solardetox Acadus-2001 (Ecosystem), based on compound para- 


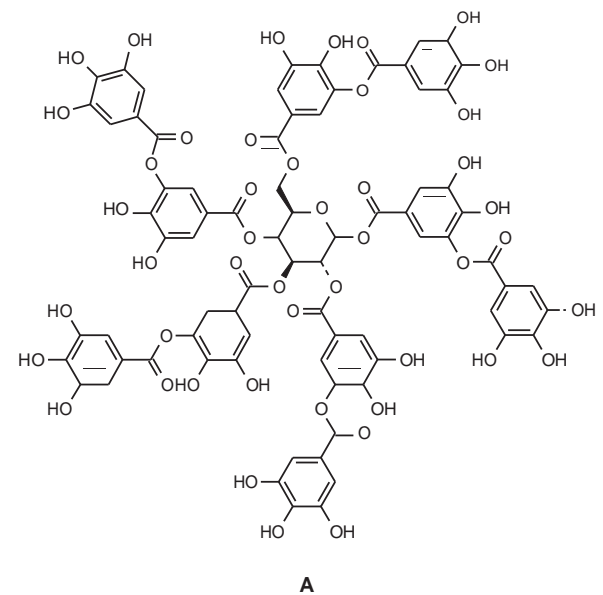<smiles>O=[N+]([O-])c1ccc(O)c([N+](=O)[O-])c1</smiles>

B<smiles>O=C(O)c1cc(O)c(O)c(F)c1</smiles>

$\mathbf{F}$<smiles>COc1cc(C(=O)O)cc([O-])c1O</smiles>

C<smiles>COc1cc(/C=C/C(=O)O)cc(OC)c1O</smiles><smiles>O=C(O)c1ccc(O)c(O)c1</smiles>

D<smiles>COc1cc(C(=O)O)ccc1O</smiles>

E

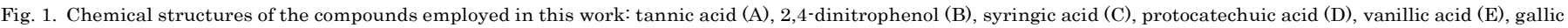
acid (F), sinapic acid (G) and ellagic acid (H).

bolic collector technology, which has been described elsewhere [28]. The total surface of the photoreactor was $0.26 \mathrm{~m}^{2}$, with an irradiated volume of $1.83 \mathrm{~L}$. The surface was tilted 30 o with the horizon. The reactor was equipped with a radiometer (Acadus $85)$ to measure UV-A radiation. The plant was loaded with $5 \mathrm{~L}$ of an aqueous solution containing the pollutants; the $\mathrm{pH}$ was adjusted to 3.9 with sulphuric acid, the concentration of $\mathrm{Fe}^{2+}$ was $3 \mathrm{mg} / \mathrm{L}$ and $\mathrm{H}_{2} \mathrm{O}_{2}$ was periodically added throughout the process. In order to normalise changing solar conditions, $t_{30 \mathrm{w}}$ was calculated according to Eq. (1), where $\mathrm{UV}_{\mathrm{ac}}$ is the accumulated UVA irradiation, $V_{i}$ and $V_{T}$ are respectively the irradiated and total volume and I the average light intensity (typically $30 \mathrm{~W} / \mathrm{m}^{2}$ is Southern Spain). This parameter has been commonly employed in photochemical processes under sunlight [29].

$t_{30 \mathrm{~W}} 1 / 4 \frac{\mathrm{UV}_{\mathrm{ac}} \cdot V_{i}}{I \cdot V_{T}}$

\subsection{Chemical analysis}

The concentration of each pollutant was determined by UHPLC (Perkin Elmer model Flexiar UPLC FX-10). A Bronwnlee Analytical column (DB-C18) was employed as stationary phase. The eluent consisted in a linear gradient of acetonitrile (A) and an aqueous solution of formic acid $(0.1 \% \mathrm{w} / \mathrm{w})(\mathrm{B})$; the composition of the eluent changed from $5 \%$ of $\mathrm{A}$ to $50 \%$ of $\mathrm{A}$ in $8.5 \mathrm{~min}$ and the flow rate was $0.3 \mathrm{~mL} \mathrm{~min}^{-1}$. Detection wavelength was $230 \mathrm{~nm}$. Identification and quantitation of the pollutants were performed by comparison with standards. Samples were filtered through polypropylene filters (VWR, $0.45 \mathrm{~lm}$ ) before analysis.

Dissolved organic carbon (DOC) was measured with a Shimadzu TOC-V CSH apparatus. The fluorescence EEM of the samples were recorded using a modular fluorimeter QuantaMaster (PTY) by a subsequent scanning emission from 300 to $600 \mathrm{~nm}$ at $5 \mathrm{~nm}$ increments by varying the excitation wavelength from 250 to $550 \mathrm{~nm}$ at $5 \mathrm{~nm}$ increments.

\subsection{Bioassays}

Toxicity tests with P. subcapitata were performed in 96-well flat bottom transparent (Costar, Corning Inc., New York, USA) according to ISO 8692:2012. The microplate was filled by automatic injector with the test dilutions and controls and inoculated with the $10^{4}$ cells $/ \mathrm{mL}$ from an exponential growth culture. The final assay volume was $300 \mathrm{IL}$ per well. Microplates were incubated at $23 \circ \mathrm{C}$ under continuous illumination (6000-10,000 lux), saturated with
$2 \% \mathrm{CO}_{2}$ and stirred at $120 \mathrm{rpm}$. The algal growth was measured by in vivo chlorophyll fluorescence every $24 \mathrm{~h}$, (until $72 \mathrm{~h}$ ) using a microplate reader (Tecan Infinite M200).

The toxicity assays were based on the inhibition of the mobility of D. magna, according to the standard ISO 6341:2012 procedure. The bioassay uses 24-h old organisms hatched from the dormant eggs, which can be activated in specific environmental conditions; the eggs developed in about 3 days of time into neonates, which were used immediately for toxicity tests. Five neonates were placed in $15 \mathrm{~mL}$ containers with $10 \mathrm{~mL}$ of test dilution and corresponding controls. The assays were conducted in the dark at a constant temperature of $21 \stackrel{\circ}{\circ}$.

Recombinant Yeast Assay (RYA) was performed as described by García Reyero et al. [30]. Yeast cells were grown overnight in a minimal synthetic medium supplemented appropriately for each strain. Assays were conducted in a polypropylene microplate (NUNC ${ }^{\mathrm{TM}}$, Roskilde, Denmark). First column was filled with the yeast culture and the preconcentrated sample [31] achieving 1:20 v/v dilution, and then diluted in a 1:2 series across the assay plate until column 9. A negative, positive and toxicity controls

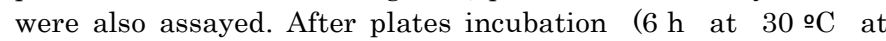
$120 \mathrm{rpm}$ in orbital shaker), Y-PER was added to each well (30 ㄷ, $30 \mathrm{~min}$ ). Then, enzymatic substrate was added to the lysed cells. After brief centrifugation, b-galactosidase activity was read by fluorescence versus time using a spectrofluorometer (TECAN Infinite M2000). A relative activity of b-galactosidase was calculated from recorded activity of positive and negative control. RYA does not provide a direct measurement of the molar concentration or mass of potentially toxic compounds but of their activities. Results were calculated as E2 equivalents (EEQ) (estrogenic activity) or b-NF (BNFEQ) (dioxin-like activity), defined as the concentration (ng/L) of standard that should be present to account for the observed response in a given sample following the method proposed by Noguerol et al. [27].

\subsection{Statistical analysis}

An experimental design methodology based on a Doehlert array was employed to evaluate the effect of three variables, namely $\mathrm{pH}$, hydrogen peroxide and iron concentration. For this purpose, a total of 15 experiments $\left(k^{2}+k+1\right.$, where $k$ is the number of analysed variables, plus two replicates of the central point) were performed (Table 1). The software Statgraphics Centurion XVI was used for response surface model fitting by means of the least squares method. The illumination time required to degrade each pollutant in a $75 \%\left(t_{75 \%}\right)$ was used as response. 
Table 1

Experimental points and response $\left(t_{75 \%}\right)$ used in the experimental design methodology based on Doehlert matrix.

\begin{tabular}{cllllr}
\hline $\begin{array}{l}\text { Experiment } \\
\text { number }\end{array}$ & $\begin{array}{l}{[\mathrm{Fe}(\mathrm{II})]} \\
(\mathrm{mg} / \mathrm{L})\end{array}$ & $\begin{array}{l}{\left[\mathrm{H}_{2} \mathrm{O}_{2}\right]} \\
(\mathrm{mg} / \mathrm{L})\end{array}$ & $\mathrm{pH}$ & $\begin{array}{l}{[\mathrm{Fe}(\mathrm{II})] /\left[\mathrm{H}_{2} \mathrm{O}_{2}\right]} \\
\text { molar ratio }\end{array}$ & $\begin{array}{r}t_{75 \%} \\
(\mathrm{~min})\end{array}$ \\
\hline 1 & 3 & 55.3 & 3.9 & 30 & 1.90 \\
2 & 5 & 55.3 & 3.9 & 18 & 2.48 \\
3 & 4 & 96.7 & 3.9 & 40 & 2.85 \\
4 & 4 & 69.1 & 5 & 28 & 1.55 \\
5 & 1 & 55.3 & 3.9 & 91 & 3.39 \\
6 & 2 & 13.8 & 3.9 & 11 & 17.89 \\
7 & 2 & 41.4 & 2.8 & 34 & 4.03 \\
8 & 4 & 13.8 & 3.9 & 6 & 8.27 \\
9 & 4 & 41.4 & 2.8 & 17 & 4.65 \\
10 & 2 & 96.7 & 3.9 & 80 & 1.49 \\
11 & 3 & 82.9 & 2.8 & 46 & 4.37 \\
12 & 2 & 69.1 & 5 & 57 & 10.60 \\
13 & 3 & 27.6 & 5 & 15 & 19.46 \\
14 & 3 & 55.3 & 3.9 & 30 & 1.65 \\
15 & 3 & 55.3 & 3.9 & 30 & 1.84 \\
& & & & &
\end{tabular}

In bioassays, toxicity data were used to calculate the MID value (sample dilution required to produce a $50 \%$ response) by Probit analysis, using the Statistical Analysis System SPSS (v. 16.0). Toxicity data were analyzed with one-way analysis of variance (ANOVA) to inspect the effect of photo-Fenton treatment time. A $p<0.05$ was taken to indicate statistical significance.

\section{Results and discussion}

\subsection{Laboratory scale experiments}

A set of laboratory scale experiments (Table 1) was carried out to determine the effect of $\mathrm{pH}$, amount of $\mathrm{H}_{2} \mathrm{O}_{2}$ and iron concentration on the photo-Fenton treatment of solutions containing a mix ture of all 8 pollutants. Although all the studied pollutants were present in the irradiated sample, with an initial concentration of $1 \mathrm{mg} / \mathrm{L}$ each, only six of them could be analysed by HPLC, as tannic and ellagic acids could not be detected, most probably due to their high molecular weight. An example of the plots of the relative concentration of each pollutant vs. time can be observed in Fig. 2. A very fast removal of the pollutants was reached in all the experiments; however, some differences in reactivity could be found among the analysed compounds, which followed the general trend: gallic acid $>$ sinapic acid $\gg$ syringic acid $=$ protocatechuic acid > vanillic acid $>2,4$-dinitrophenol. This order is ruled by the substitution of the aromatic ring, as the reaction of hydroxyl radical to aromatic rings involves an electrophilic attack of $\mathrm{OH}$ to the ring as described for nitrophenol [9]. Hence, compounds having three activating electron-donating groups attached to the aromatic ring (hydroxy or methoxy) react faster than those having only two groups; dinitrophenol is the most reluctant, as its aromatic ring bears two strongly deactivating electron-withdrawing nitro groups. These trends have already been observed in the oxidation of families of phenolic compounds according to different AOPs $[4,32]$.

The time required to reduce in a $75 \%$ the initial concentration of 2,4 -dinitrophenol $\left(t_{75 \%}\right)$ was employed as response for the statistical calculation; this compound was chosen as it is the most reluctant to photo-Fenton among the ones analysed, as removal of other pollutants was too fast to obtain reliable data $\left(t_{75 \%}<1 \mathrm{~min}\right.$ for most experiments). Furthermore, 4-dinitrophenol shows the highest toxicity (see Section 3.3). Based on $t_{75 \%}$, a three-dimensional full quadratic response surface model was obtained (Eq. (2)), where $\left[\mathrm{H}_{2} \mathrm{O}_{2}\right]$ and $[\mathrm{Fe}(\mathrm{II})]$ are expressed as $\mathrm{mg} / \mathrm{L}$ and $t_{75 \%}$ in minutes:

$$
\begin{aligned}
& \left.t_{75 \%} 1 / 418: 62 \mathrm{p} 5: 30 \cdot 1 / 2 \mathrm{Fe} \text { ðIIP] - 0:25 } 1 \frac{1}{2} \mathrm{H}_{2} \mathrm{O}_{2}\right]-9: 05 \cdot \mathrm{pH} \\
& \text { p 0:28.1/2FeðIIP] }{ }^{2} \text { p 0:07 } 1 / 2 \mathrm{Fe} \text { ðIIP] } \cdot 1 / 2 \mathrm{H}_{2} \mathrm{O}_{2} \text { ] } \\
& \text { - 3:03 ·1 1/2FeðIIP] } \cdot \mathrm{pHp} 0: 003 \cdot 1 / 2 \mathrm{H}_{2} \mathrm{O}_{2} \text { ] } \\
& \left.-0: 11 \cdot 1 / 2 \mathrm{H}_{2} \mathrm{O}_{2}\right] \cdot \mathrm{pHp} 3: 49 \cdot \mathrm{pH}^{2}
\end{aligned}
$$

The value of the determination coefficient $\left(R^{2}\right)$ was 0.97 , indicating good correspondences between experimental and calculated data. In each case, the values of the residuals as a function of measured values were randomly distributed. Pareto charts (Fig. S1) show that all factors were significant except for $\left[\mathrm{Fe}(\mathrm{III}]^{2}\right.$.

In order to appreciate better the effect of the studied operational variables, bi-dimensional curves were obtained by fixing each parameter at its higher, central and lower values. Data fixing $\mathrm{pH}$ at 2.8, 3.9 and 5 can be found in Fig. 3. The plot obtained at $\mathrm{pH}=3.9$ shows that reaction rate increased with the amount of $\mathrm{H}_{2} \mathrm{O}_{2}$ and that a slight acceleration of the process occurred at higher iron concentrations. It is interesting to indicate that beyond $40-60 \mathrm{mg} / \mathrm{L}$ of $\mathrm{H}_{2} \mathrm{O}_{2}$, the reaction was so fast that extra addition of this reagent did not result in a positive effect. At $\mathrm{pH}=2.8$, the reaction was slightly faster than at $\mathrm{pH}=3.9$ at low concentrations of peroxide, while there was some loss of efficiency at higher concentrations of this reagent. This might be due to the fast generation of reactive species (e.g. hydroxyl radical) that resulted in their recom-

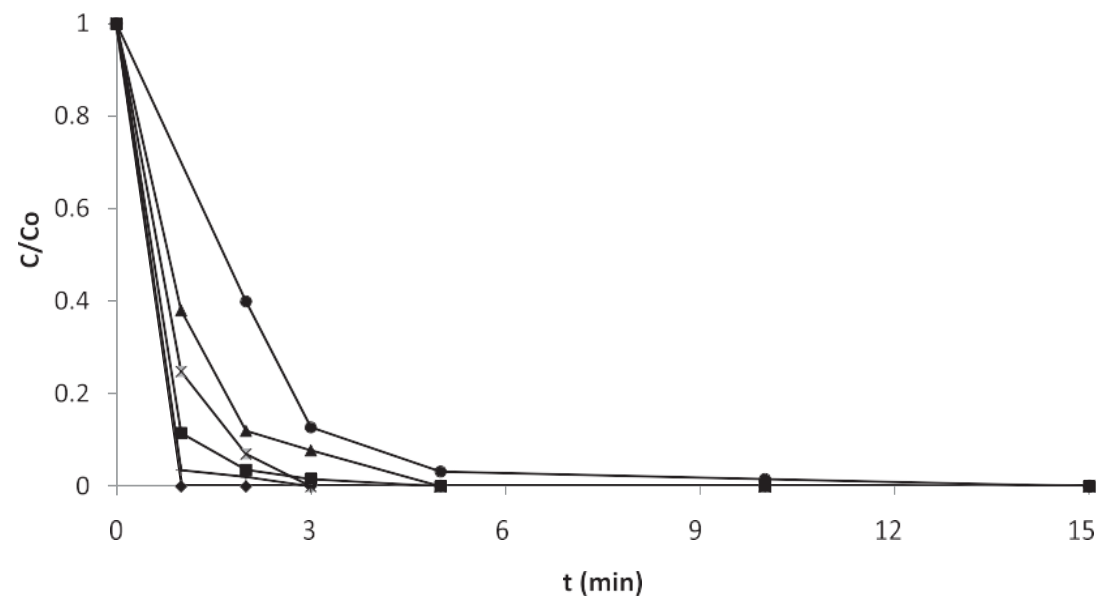

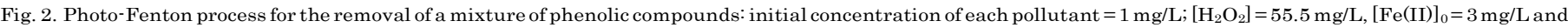

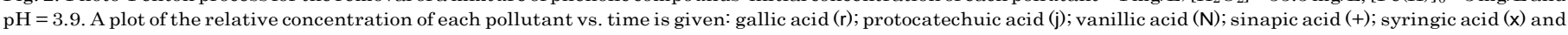
2,4-dinitrophenol (d). 

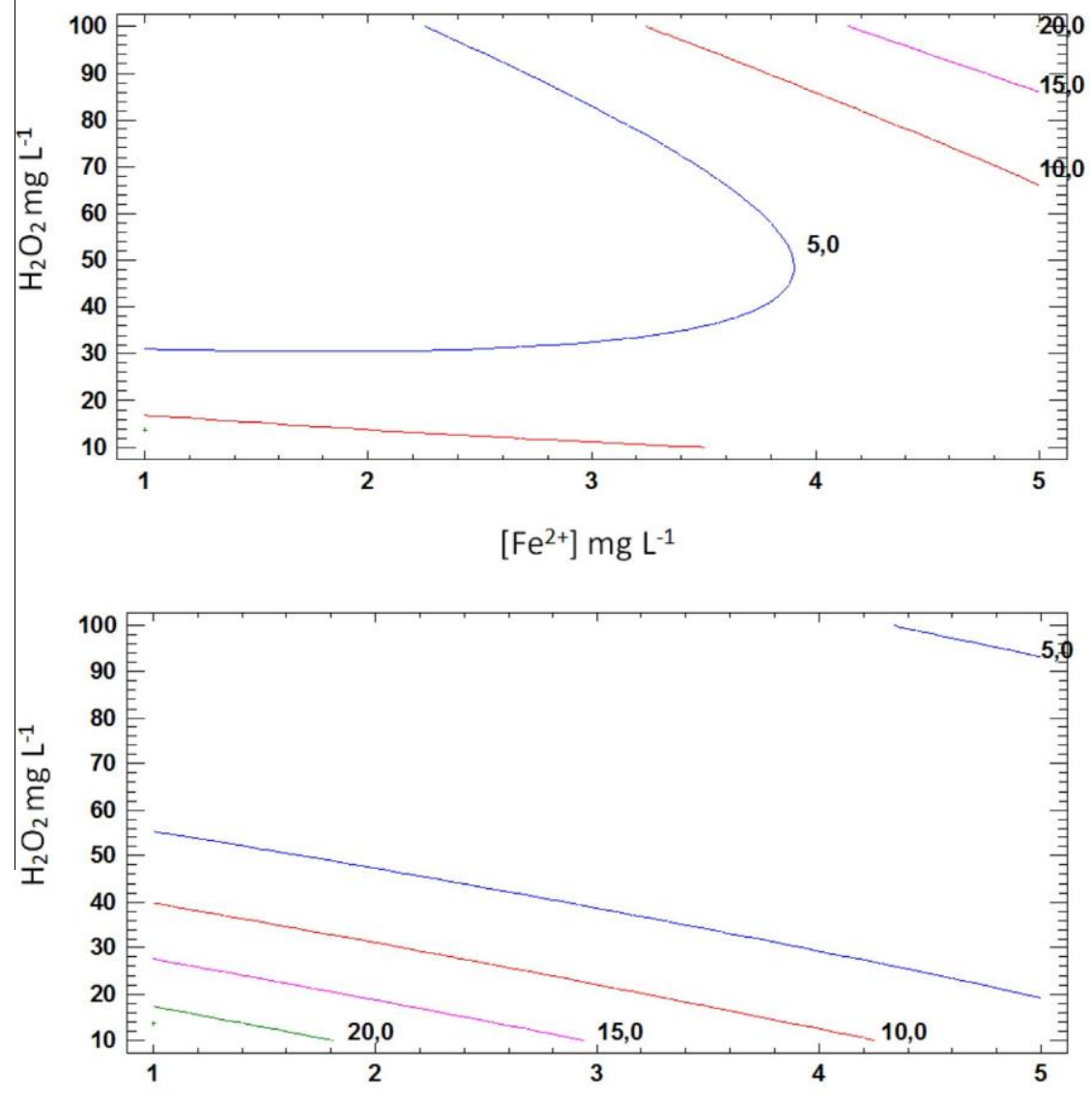

$\left[\mathrm{Fe}^{2+}\right] \mathrm{mg} \mathrm{L}^{-1}$

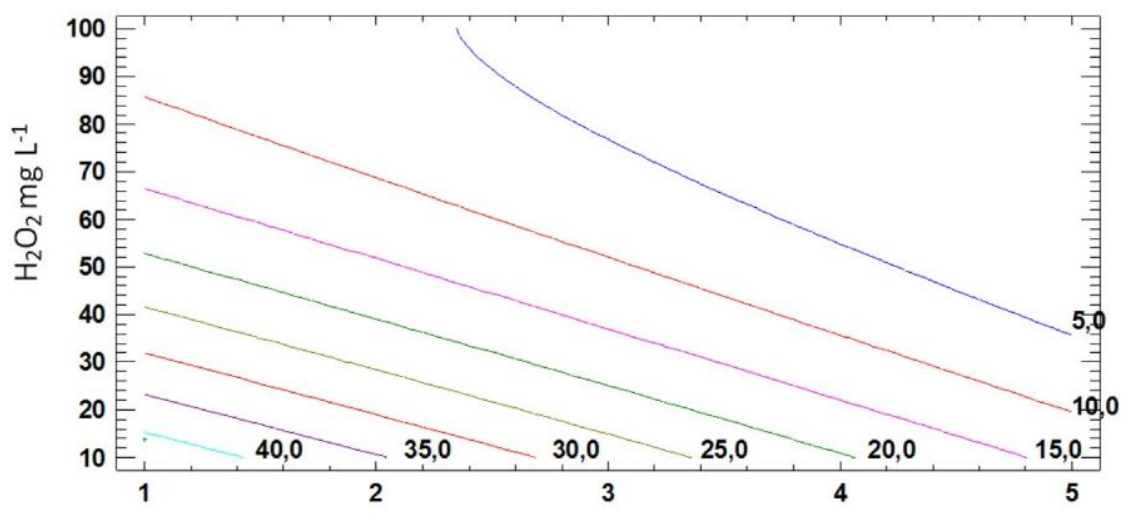

$\left[\mathrm{Fe}^{2+}\right] \mathrm{mg} \mathrm{L}^{-1}$

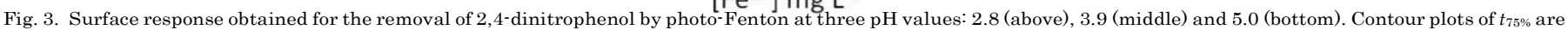
plotted vs. concentrations of $\mathrm{H}_{2} \mathrm{O}_{2}$ and $\mathrm{Fe}$ (II).

bination, hence decreasing the probability of reaction with the pollutants [33]. At $\mathrm{pH}=5$, photo-Fenton was less efficient, but best results were reached at the highest $\left[\mathrm{H}_{2} \mathrm{O}_{2}\right]$.

Regarding to iron concentration (Fig. 4), $t_{75 \%}$ was below $5 \mathrm{~min}$ in the domain where $\left[\mathrm{H}_{2} \mathrm{O}_{2}\right]>40 \mathrm{mg} / \mathrm{L}$ for all iron concentrations, although the effect of $\mathrm{pH}$ was different in all three cases. For [Fe] $=1 \mathrm{mg} / \mathrm{L}$, reaction rate decreased with increasing $\mathrm{pH}$, at $[\mathrm{Fe}]$ $=3 \mathrm{mg} / \mathrm{L}$ the increase of $t_{75 \%}$ was only observed at $\mathrm{pH}>4$, and for $[\mathrm{Fe}]=5 \mathrm{mg} / \mathrm{L}$, pH was not very relevant in the studied domain. These results might be ruled by the iron availability as at high iron concentration, the process is efficient enough even at $\mathrm{pH}$ close to 5 , while at low concentration, conditions closer to the optimum (2.8) are required.
When the amount of $\mathrm{H}_{2} \mathrm{O}_{2}$ (Fig. 5) was fixed at their central value $(55.3 \mathrm{mg} / \mathrm{L})$, the reaction was very fast at low $\mathrm{pH}$ values ( $t_{75 \%}$ below $5 \mathrm{~min}$ until $\mathrm{pH}$ of ca. 4 ) and at high concentration of iron the decrease in the reaction rate was negligible until $\mathrm{pH}=5$. At the lowest $\left[\mathrm{H}_{2} \mathrm{O}_{2}\right]$, the reaction was slower $\left(t_{75 \%}>5 \mathrm{~min}\right)$, most probably due to the lower availability of the oxidising agent, and best results were achieved at low $\mathrm{pH}$ and high iron concentration. On the other hand, at the highest $\left[\mathrm{H}_{2} \mathrm{O}_{2}\right]$ trends were opposite: photo-Fenton was efficient even at high $\mathrm{pH}$ values (4.5 and even above when iron concentration was high) while at low $\mathrm{pH}$ and high $\left[\mathrm{Fe}^{2+}\right]$ there was a loss of efficiency which can be attributed to the recombination of $\mathrm{OH}$ or to reaction of $\mathrm{OH}$ with hydrogen peroxide, due to the excess of oxidising agent. 

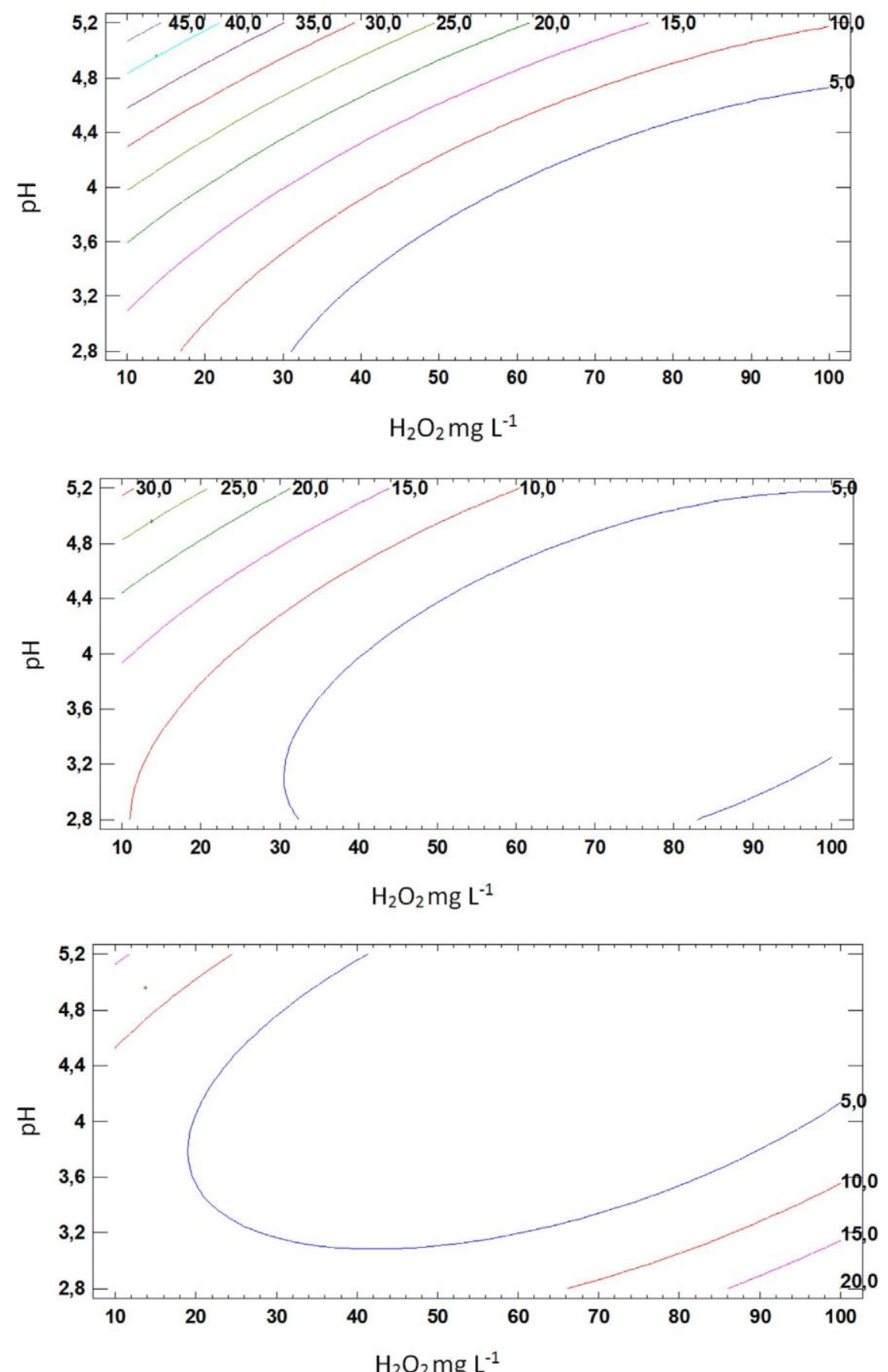

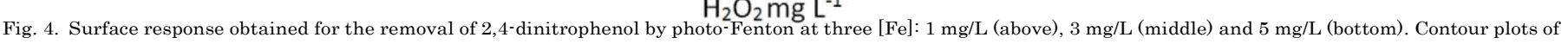
$t_{75 \%}$ are plotted vs. concentration of $\mathrm{H}_{2} \mathrm{O}_{2}$ and $\mathrm{pH}$.

Putting together the above reported results, $\left[\mathrm{H}_{2} \mathrm{O}_{2}\right]$ should be slightly above $40 \mathrm{mg} / \mathrm{L}$ (extra addition of this reagent does not result in a faster reaction) and $\mathrm{pH}$ can be extended to values close to 4 if there is enough iron availability. For this reason, a combination of $\mathrm{pH}=3.9,\left[\mathrm{H}_{2} \mathrm{O}_{2}\right]=55 \mathrm{mg} / \mathrm{L}$ and $\left[\mathrm{Fe}^{2+}\right]=3 \mathrm{mg} / \mathrm{L}$, which is the central point of the experimental design, could be considered within the most convenient region to carry out this process. The good performance of photo-Fenton at $\mathrm{pH} 3.9$ can be attributed to the complexation of iron with the phenolic species as it has been reported that the optimum $\mathrm{pH}$ for the photo-Fenton process can be shifted towards higher value, due to changes in the complexation sphere of iron [20]. In this case, phenolic acids can form complexes with iron, thus explaining this apparently anomalous result.
In fact, it has been recently published that cinnamic acids can be efficiently degraded at $\mathrm{pH}$ ca. 5 by Fenton process in a sucrose solution because of the ability of those compounds to form complexes with iron [34].

Mineralisation after 120 min of irradiation was in most cases in the range $50-65 \%$, including the central point, whose mineralisation was ca. $60 \%$ (data not shown). Values below $50 \%$ were only obtained for a few experiments with low $\mathrm{H}_{2} \mathrm{O}_{2}$ and iron concentration and high $\mathrm{pH}$ values. This indicates that although photo-Fenton is able to remove efficiently the monitored phenolic compounds, important amounts of organics remain in the reaction medium, either as by products from the degradation of these compounds or from the non-monitored polyphenols, (ellagic or tannic acid). 

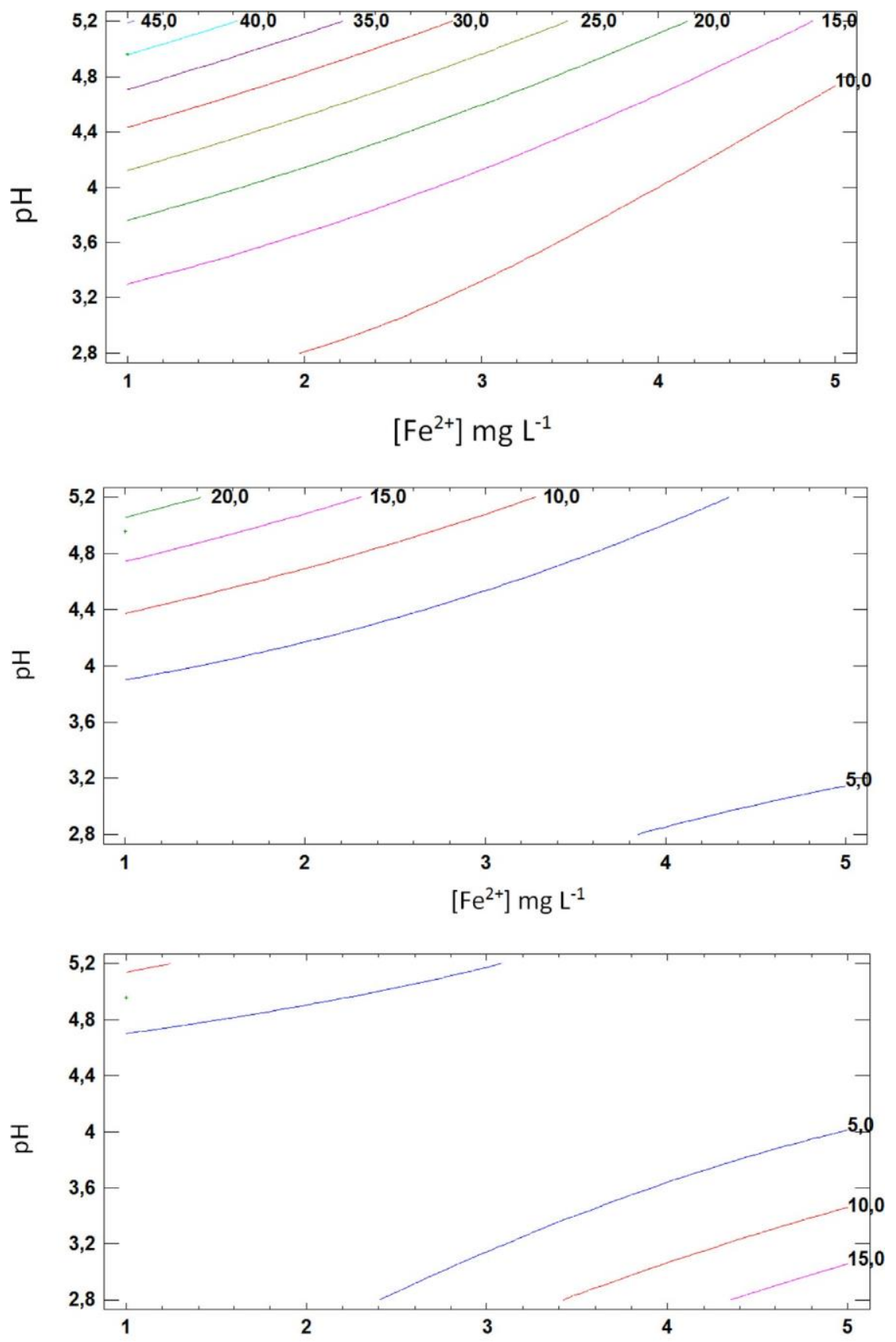

$\left[\mathrm{Fe}^{2+}\right] \mathrm{mg} \mathrm{L}^{-1}$

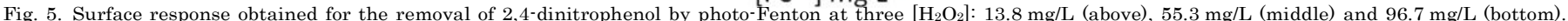
Contour plots of $t_{75 \%}$ are plotted vs. concentration of $\mathrm{Fe}$ and $\mathrm{pH}$.

Hence, further assays are required to assess the actual performance of the process.

\subsection{Pilot plant experiments}

Experiments were performed under real solar irradiation in a pilot plant for wastewater detoxification; the $\mathrm{pH}$ was 3.9 , the amount of iron $3 \mathrm{mg} / \mathrm{L}$ and $\mathrm{H}_{2} \mathrm{O}_{2}$ was monitored throughout the process and added when required. Fig. 6 shows the removal of each pollutant, the remaining DOC, the amount of iron in the solution and hydrogen peroxide consumption. A fast removal of the pollutants was achieved, as even 2,4-dinitrophenol, the most refractory compound, was not detected after 2.2 min of normalised irradia- tion time. Although mineralisation also occurred (ca. 50\% DOC removal after $4 \mathrm{~min}$ of irradiation), when the primary pollutants we removed nearly $70 \%$ of the initial DOC remained in the solution. Although there was some iron precipitation throughout the process, most probably forming photochemically inactive oxides or hydroxides [15], [Fe] was still ca. $2 \mathrm{mg} / \mathrm{L}$ at $t_{30 \mathrm{w}}=65 \mathrm{~min}$ (see Fig. 6). Finally, hydrogen peroxide consumption was high in the first part of the process $(50 \mathrm{mg} / \mathrm{L}$ in the first $15 \mathrm{~min})$ and then, consumption rate decreased. The ratio between $\mathrm{H}_{2} \mathrm{O}_{2}$ consumed and DOC decrease was calculated as an alternative indicator of the efficiency of the process, as shows the amount of oxidising agent required to decrease $1 \mathrm{mg}$ of DOC (the higher the ratio, the lower the efficiency). At the beginning, the efficiency was high (less than 


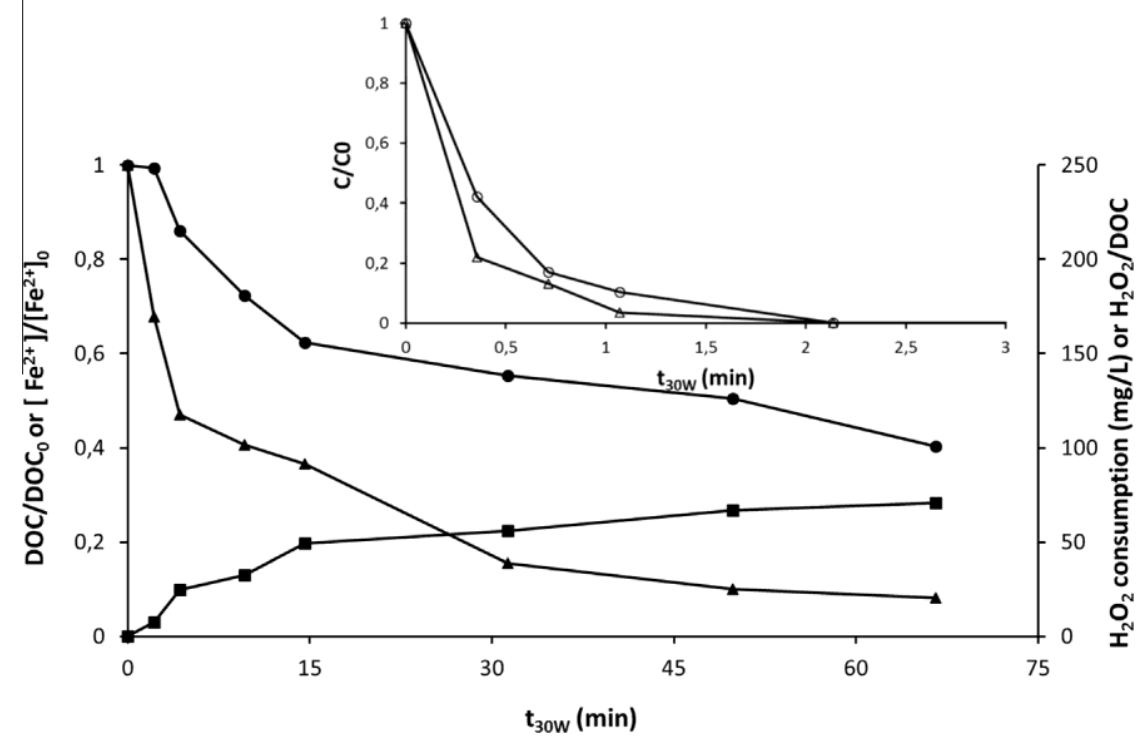

Fig. 6. Photo-Fenton treatment of a mixture of phenolic compounds at pilot plant under real sunlight: (d) relative iron concentration, (N) relative DOC amount and hydrogen peroxide consumption (j). Inset: removal of the phenolic compounds: (s) 2,4-dinitrophenol, (4) vanillic acid. All other compounds were removed at the first sampling time.

$15 \mathrm{mg}$ of $\mathrm{H}_{2} \mathrm{O}_{2}$ were required per $\mathrm{mg}$ of $\mathrm{DOC}$ for $t_{30 \mathrm{~W}}$ below $10 \mathrm{~min}$ ), but values above $200 \mathrm{mg}$ of $\mathrm{H}_{2} \mathrm{O}_{2}$ per $\mathrm{mg}$ of DOC were reached at $t_{30 \mathrm{w}}=50 \mathrm{~min}$.

As an important amount of DOC remained in the solution, it is necessary to perform new experiments in order to gain further insight into the nature and biocompatibility of the remaining organics. GC analyses were carried out to identify some major compounds present in the sample, but it was impossible to obtain reliable identification of the photoproducts as there were many peaks with very low intensity. This was due to the complexity of the initial sample, consisting in a mixture of 8 compounds, two of them polyphenols. Hence, it is necessary either to employ very sophisticated analytical tools or to explore a new methodology to deal with such complex mixtures, combining a battery of bioassays to check the biocompatibility of the treated mixture, with the use of EEM fluorimetry to gain further insight into the composition of the remaining organics. Sections 3.3 and 3.4 are devoted to this purpose.

\subsection{Bioassays}

As complete mineralisation of the mixture was not achieved, but very short irradiation periods were required to remove the primary phenolic pollutants, it was interesting to monitor changes in the toxicity of the mixture to rule out the formation of toxic byproducts. A preliminary battery of bioassays was performed with the pure pollutants in order to stablish their toxicity towards $P$. subcapitata, D. magna as well as their estrogenic and dioxin-like activities. The highest toxicity was recorded for 2,4-dinitrophenol $\left(\mathrm{EC}_{50}\right.$ of 0.7 and $12.4 \mathrm{mg} / \mathrm{L}$ for P. subcapitata and D. magna, respectively), followed by protocatechuic acid and both polyphenolic substances, tannic and ellagic acids, whose $\mathrm{EC}_{50}$ for $P$. subcapitata was in the range $10-20 \mathrm{mg} / \mathrm{L}$ and ca. $50 \mathrm{mg} / \mathrm{L}$ for $D$. magna; the toxicity of other phenolic acids was significantly lower. Regarding to endocrine disruption capacity, the highest effect was found for 2,4 dinitrophenol (3.2 ng/L E2 equivalents). Protocatechuic, tannic and vanillic acids also showed some estrogenic effect (slightly above $1 \mathrm{ng} / \mathrm{L} \mathrm{E} 2$ equivalents) and it was lower for the other compounds (below $1 \mathrm{ng} / \mathrm{L}$ ). Highest value for dioxin-like activity was also obtained for 2,4-dinitrophenol, thus showing that this is, according to all methods, the most hazardous chemical among those present in the mixture.
Toxicity was monitored along the photo-Fenton process according to the methods described above. In order to obtain samples free of $\mathrm{H}_{2} \mathrm{O}_{2}$ a controlled amount of this reagent was added and the solution was irradiated in the solar plant until complete exhaustion of $\mathrm{H}_{2} \mathrm{O}_{2}$. As accurate irradiation period could not be obtained because of the lack of $\mathrm{H}_{2} \mathrm{O}_{2}$, DOC of the sample was compared with the DOC vs $t_{30}$ profile obtained in Section 3.2 (Fig. 6) to estimate the equivalent $t_{30 \mathrm{w}}$. Table 2 shows that high toxicity was obtained for the untreated sample according to D. magna and $P$. subcapitata assays ( $65 \%$ and $71 \%$ respectively). There was a very fast detoxification at the early stages of the process, in coincidence with the removal of the primary pollutants; beyond this point, there was some oscillation in toxicity, although it remained low. This remnant toxicity could be due to the release of bio-active byproducts from the degradation of ellagic acid and tannic acid. A similar behaviour was observed for the estrogenic activity; the nontreated mixture was too toxic to measure this parameter. The first treated sample showed an estrogenic activity equivalent to 7 $\mathrm{ng} / \mathrm{L}$ of $\mathrm{E} 2$ and the sample $2\left(t_{30 \mathrm{~W}}=6 \mathrm{~min}\right)$ of $1.2 \mathrm{ng} / \mathrm{L}$. Values below $2 \mathrm{ng} / \mathrm{L}$ were systematically reached after $t_{30 \mathrm{w}}=15 \mathrm{~min}$. These levels may potentially cause endocrine disruption in different aquatic species. Adverse effects were observed in vivo exposure experiments in both flow-through and static systems. Jobling et al. [35] reported effects on vitellogenin production and testicular growth in sexually maturing male rainbow trout exposed during 3 weeks to a concentration of $2 \mathrm{ng} / \mathrm{L}$ E2 .

In contrast, the dioxin-like behaviour could not be supressed: although there was an initial decrease, it increased again at the end of the process. This could also be attributed to the release of intermediates from the polyphenols present in the mixture. The effect of dioxin-like compounds on the vertebrate include neurologic, immunologic, and reproductive parameters [36]. Hence, this is a concern that must be further studied in future work.

\subsection{Fluorescence measurements}

As indicated above, application of mass spectroscopy to gain further insight into the composition of the photo treated mixture would require sophisticated equipment and time-consuming preparation of the samples to obtain reliable results. For this reason, it is meaningful to explore EEM as a good alternative to monitor major changes in the composition of organic fraction. 


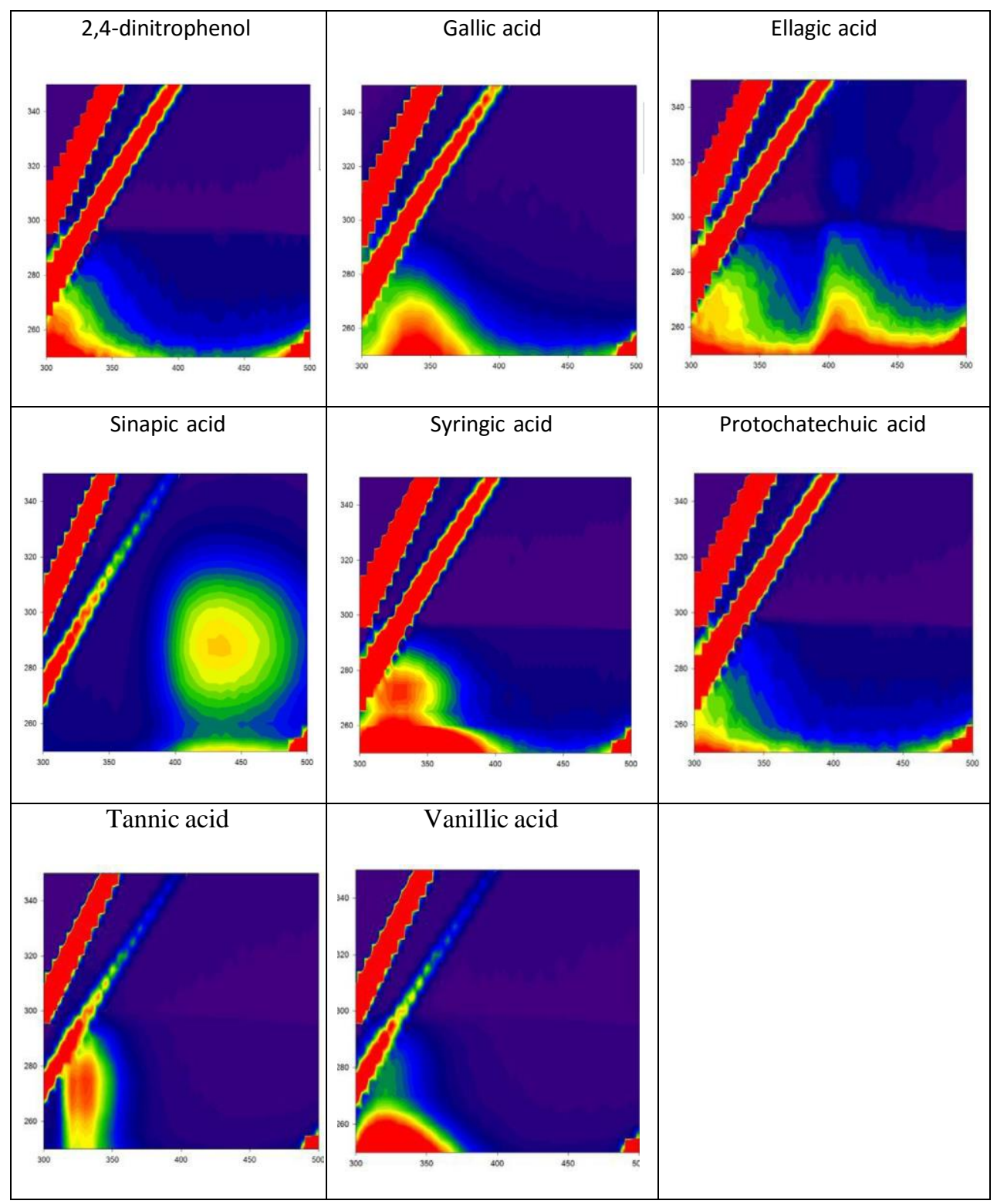

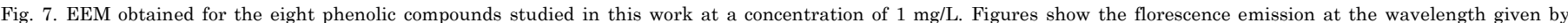

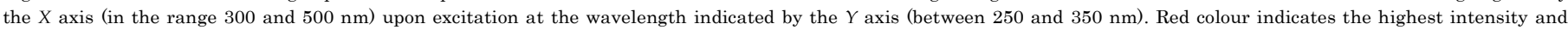
blue colour the lowest. (For interpretation of the references to colour in this figure legend, the reader is referred to the web version of this article.)

EEM were obtained for all eight compounds (Fig. 7). In general, phenolic acids show excitation in the range $250-280 \mathrm{~nm}$ and emission at $300-370 \mathrm{~nm}$, reaching in some cases $400 \mathrm{~nm}$ (syringic acid); the response of 2,4-dinitrophenol can also be found within this region; sinapic acid, most probably due to the presence of exocyclic double bond, shows an excitation band between 270 and $310 \mathrm{~nm}$ and emits at $400-450 \mathrm{~nm}$; for tannic acid, excitation is in 250-290 nm and emission in 310-340. Finally, ellagic acid excitation band is below $280 \mathrm{~nm}$ and has two emissions, below 290 and between 390 and $430 \mathrm{~nm}$.

EEM were recorded throughout the photo-Fenton process at different sampling times (Fig. 8). The non-treated sample showed a saturated signal in the region $k_{\mathrm{exc}}<300 \mathrm{~nm}$ and $\mathrm{k}_{\mathrm{em}}<430 \mathrm{~nm}$, which is the result of the addition of the contribution of each single component. The treatment resulted in a fast decrease of the signal, already observed at the sample taken at $0.4 \mathrm{~min}$, which is an indicator of the efficiency of the photo-Fenton under the studied conditions. Differences in reactivity reported in Section 3.1 can also be
Table 2

Biological risks associated to the mixture of phenolic compounds along a photoFenton process in pilot plant at a $\mathrm{pH}$ of 3.9: toxicity, estrogenic activity and dioxin like behaviour.

\begin{tabular}{llrlll}
\hline $\begin{array}{lllll}\text { Sample } \\
\text { number }\end{array}$ & $\begin{array}{l}t_{30 \mathrm{w}} \\
(\mathrm{m})\end{array}$ & \multicolumn{2}{l}{ Toxicity $(\%)$} & $\begin{array}{l}\text { Estrogenic } E_{2} \\
\text { (ng/L) }\end{array}$ & $\begin{array}{l}\text { Dioxin-like } \\
\text { BNF }(\mathrm{ng} / \mathrm{L})\end{array}$ \\
\cline { 3 - 5 } & & $\begin{array}{l}\text { D. } \\
\text { magna }\end{array}$ & $\begin{array}{l}\text { P. } \\
\text { subcapitata }\end{array}$ & \\
\hline 0 & 0 & 65 & 71.3 & Very toxic & 88 \\
1 & 2.5 & 0 & 4.2 & 7.0 & 67 \\
2 & 6 & 25 & 12.6 & 1.2 & 23 \\
3 & 22 & 15 & 15.6 & 0.6 & 67 \\
4 & 34 & 0 & 21.9 & 0.2 & 82 \\
5 & 51 & 0 & 13.6 & 0.5 & 70 \\
\hline
\end{tabular}

appreciated in EEM. For instance, peaks attributable to sinapic acid had completely disappeared at $t=1.1 \mathrm{~min}$, while that of syryngic still remained after $t=3.2 \mathrm{~min}$. Regarding to polyphenols, there was a certain increase of emission in the area attributable to ellagic 


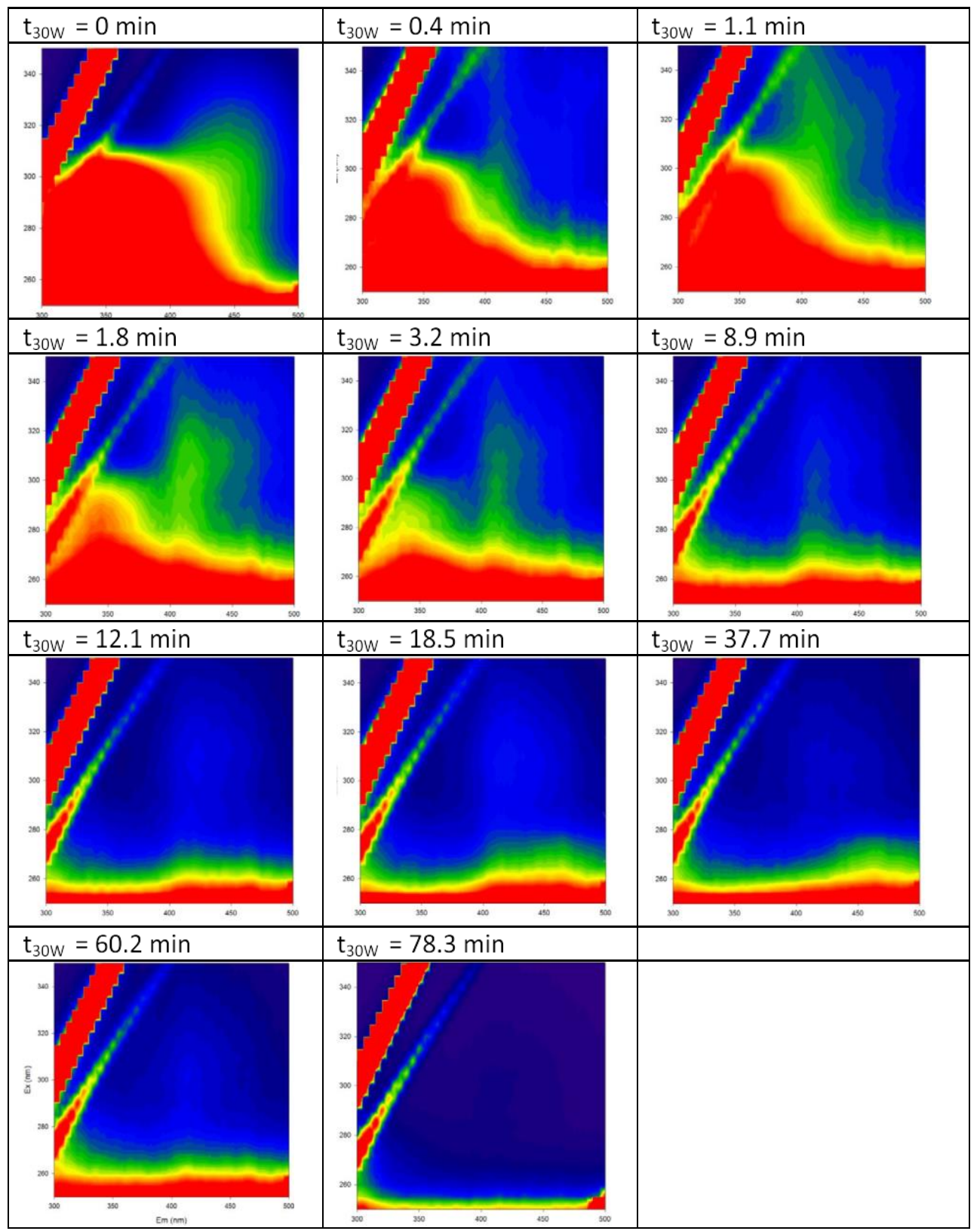

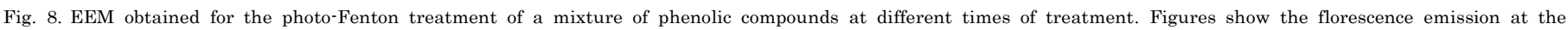

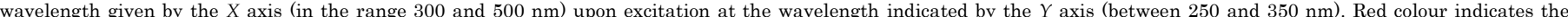
highest intensity and blue colour the lowest. (For interpretation of the references to colour in this figure legend, the reader is referred to the web version of this article.)

acid, which could be due to the release of moieties bearing similar chromophores as a consequence of the oxidation of tannic acid. In any case, for irradiation times longer than $12 \mathrm{~min}$, all the chromophores have nearly disappeared, thus showing the destruction of complex moieties in the mixture (e.g. aromaticity).

\section{Conclusions}

Photo-Fenton process has been demonstrated to be efficient to remove phenolic compounds under simulated and real sunlight. The treatment can be carried out at milder $\mathrm{pH}$ values (e.g. 4), most probably due to the complexation of iron with the phenolic groups. As phenols are commonly present in wastewaters, assessing the effect of $\mathrm{pH}$ seems interesting as in some cases might vary from 2.8 , thus decreasing the costs associated with $\mathrm{pH}$ modification.

Application of different assays to monitor changes in the biocompatibility seems advisable, as conclusions might not be always significant when based on a single assay. Hence, it seems interesting to keep on studying the applicability of novel methodology, as done in this work with the RYA assay.

Finally, EEM fluorimetry seems a simple and interesting tool to gain further insight into the behaviour of organic matter in the process. Application of mathematic methods for deconvolution of the obtained matrixes is expected to provide more detailed information on the sample composition and seems a logical step forward for this research.

\section{Acknowledgements}

The authors want to thank the financial support of the Spanish Ministerio de Educación y Ciencia (CTQ2012-38754-C03-02) and Generalitat Valenciana (GV/2015/074). Sara García-Ballesteros would like to thank Spanish Ministerio de Economía y Competitividad for her fellowship (BES-2013-066201). 


\section{References}

[1] D.C. Santos, L. Silva, A. Albuquerque, R. Simões, A.C. Gomes, Biodegradability enhancement and detoxification of cork processing wastewater molecular size fractions by ozone, Bioresour. Technol. 147 (2013) 143-151.

[2] L.A. Ioannou, G. Li Puma, D. Fatta-Kassinos, Treatment of winery wastewater by physicochemical, biological and advanced processes: a review, J. Hazard. Mater. 286 (2015) 343-368.

[3] S. Vilhunen, M. Sillanpaa, Recent developments in photochemical and chemical AOPs in water treatment: a mini-review, Rev. Environ. Sci. Biotechnol. 9 (2010) 323-330.

[4] D. Juretic, H. Kusic, N. Koprivanac, A. Loncaric Bozic, Photooxidation of benzene-structured compounds: influence of substituent type on degradation kinetic and sum water parameters, Water Res. 46 (2012) 3074-3084.

[5] D. Juretic, H. Kusic, D.D. Dionysiou, A. Loncaric Bozic, Environmental aspects of photooxidative treatment of phenolic compounds, J. Hazard. Mater. 262 (2013) 377-386.

[6] I. Michael, A. Panagi, L.A. Ioannou, Z. Frontistis, D. Fatta-Kassinos, Utilizing solar energy for the purification of olive mill wastewater using a pilot-scale photocatalytic reactor after coagulation-flocculation, Water Res. 60 (2014) 2840.

[7] E. De Torres-Socías, I. Fernández-Calderero, I. Oller, M.J. Trinidad-Lozano, F.J. Yuste, S. Malato, Cork boiling wastewater treatment at pilot plant scale: comparison of solar photo-Fenton and ozone $\left(\mathrm{O}_{3}, \mathrm{O}_{3} / \mathrm{H}_{2} \mathrm{O}_{2}\right)$. Toxicity and biodegradability assessment, Chem. Eng. J. 234 (2013) 232-239.

[8] V. Kavitha, K. Palanivelu, Destruction of cresols by Fenton oxidation process, Water Res. 39 (2005) 3062-3072.

[9] V. Kavitha, K. Palanivelu, Degradation of nitrophenols by Fenton and photoFenton processes, J. Photochem. Photobiol. A: Chem. 170 (2005) 83-95.

[10] A.M.T. Silva, E. Nouli, A.C. Carmo-Apolinario, N.P. Xekoukoulotakis, D. Mantzavinos, Sonophotocatalytic $/ \mathrm{H}_{2} \mathrm{O}_{2}$ degradation of phenolic compounds in agro-industrial effluents, Catal. Today 124 (2007) 232-239.

[11] A.M. Amat, A. Arques, M.A. Miranda, F. López, Use of ozone and UV in the treatment of effluents from board paper industry, Chemosphere 60 (2005) 1111-1117.

[12] A.M. Amat, A. Arques, F. López, M.A. Miranda, Solar photocatalysis to remove paper mill wastewater pollutants, Sol. Energy 79 (2005) 393-401.

[13] D. Mantzavinos, E. Psillakis, Enhancement of biodegradability of industrial wastewaters by chemical oxidation pre-treatment, J. Chem. Technol. Biotechnol. 79 (2004) 431-454.

[14] I. Oller, S. Malato, J.A. Sánchez-Pérez, Combination of advanced oxidation processes and biological treatments for wastewater decontamination-A review, Sci. Total Environ. 409 (2011) 4141-4166.

[15] J.J. Pignatello, E. Oliveros, A. MacKay, Advanced oxidation processes for organic contaminant destruction based on the Fenton reaction and related chemistry, Crit. Rev. Environ. Sci. Technol. 36 (2006) 1-84.

[16] S. Malato, P. Fernández-Ibáñez, M.I. Maldonado, J. Blanco, W. Gernjiak, Decontamination and disinfection of water by solar photocatalysis: recent overview and trends, Catal. Today 147 (2009) 1-59.

[17] M. Crane, C. Watts, T. Boucard, Chronic aquatic environmental risks from exposure to human pharmaceuticals, Sci. Total Environ. 367 (2006) 23-41.

[18] V.F. Fuhrman, A. Tal, S. Arnon, Why endocrine disrupting chemicals (EDCs) challenge traditional risk assessment and how to respond, J. Hazard. Mater. 286 (2015) 589-611.
[19] A. Machulek, J.E.F. Moraes, C. Vautier-Giongo, C.A. Silverio, L.C. Friedrich, C.A.O. Nascimento, M.C. González, F. Quina, Abatement of the inhibitory effect of chloride anions on the photo-Fenton process, Environ. Sci. Technol. 41 (2007) 8459-8463.

[20] J. Gomis, L. Carlos, A. Bianco Prevot, A.C.S.C. Teixeira, M. Mora, A.M. Amat, R. Vicente, A. Arques, Bio-based substances from urban waste as auxiliaries for solar photo-Fenton treatment under mild conditions: optimization of operational variables, Catal. Today 240 (2015) 39-45.

[21] A. Nebbioso, A. Piccolo, Molecular characterization of dissolved organic matter (DOM): a critical review, Anal. Bioanal. Chem. 405 (2013) 109-124.

[22] L. Yang, J. Hur, W. Zhuang, Occurrence and behaviours of fluorescence EEMPARAFAC components in drinking water and wastewater treatment system and their applications: a review, Environ. Sci. Pollut. Res. 22 (2015) 65006510 .

[23] S.M. Azcarate, A. de Araújo Gomes, M.R. Alcaraz, M.C.U. de Araújo, J.M. Camiña, H.C. Goicoechea, Modelling excitation-emission fluorescence matrices with pattern recognition algorithms for classification of Argentine white wines according grape variety, Food Chem. 184 (2015) 214-219.

[24] A. Bernabeu, S. Palacios, R. Vicente, R.F. Vercher, S. Malato, A. Arques, A.M. Amat, Solar photo-Fenton at mild conditions to treat a mixture of six emerging pollutants, Chem. Eng. J. 198-199 (2012) 65-72.

[25] L. Carlos, D.O. Mártire, M.C. Gonzalez, J. Gomis, A. Bernabeu, A.M. Amat, A. Arques, Photochemical fate of a mixture of emerging pollutants in the presence of humic substances, Water Res. 46 (2012) 4732-4740.

[26] M.A. Bezerra, R.E. Santelli, E.P. Oliveira, L.S. Villar, L.A. Escaleira, Response surface methodology (RSM) as a tool for optimization in analytical chemistry, Talanta 76 (2008) 965-977.

[27] T.N. Noguerol, S. Boronat, S. Jarque, D. Barceló, B. Piña, Detection of hormone receptor ligands in yeast by fluorogenic methods, Talanta 69 (2006) 351-358.

[28] J. Soler, A. García-Ripoll, N. Hayek, P. Miró, R. Vicente, A. Arques, A.M. Amat, Effect of inorganic ions on the solar detoxification of water polluted with pesticides, Water Res. 43 (2009) 4441-4450

[29] A. García-Ripoll, A.M. Amat, A. Arques, R. Vicente, M.F. López, I. Oller, M.I. Maldonado, W. Gernjak, Increased biodegradability of Ultracid ${ }^{\mathrm{TM}}$ in aqueous solutions with solar $\mathrm{TiO}_{2}$ photocatalysis, Chemosphere 68 (2007) 293-300.

[30] N. García-Reyero, E. Grau, M. Castillo, M. López de Alda, D. Barceló, B. Piña, Monitoring of endocrine disruptors in surface waters by the yeast recombinant assay, Environ. Toxicol. Chem. 20 (2001) 1152-1158.

[31] J. Sánchez-Avila, M. Fernández-Sanjuan, J. Vicente, S. Lacorte, Development of a multi-residue method for the determination of organic micropollutants in water, sediment and mussels using gas chromatography-tandem mass spectrometry, J. Cromatogr. A 1218 (2011) 6799-6811.

[32] M.A. Miranda, A.M. Amat, A. Arques, F. Galindo, Pyrylium salt-photosensitised degradation of phenolic contaminants presents in olive oil wastewaters with solar light. Part II: benzoic acids derivatives, Appl. Catal. B: Environ. 30 (2001) 437-444.

[33] L. Santos-Juanes, J.L. García Sánchez, J.L. Casas López, I. Oller, S. Malato, J.A. Sánchez Pérez, Dissolved oxygen concentration: a key parameter in monitoring the photo-Fenton process, Appl. Catal. B Environ. 104 (2011) 93169323.

[34] D.M.T. Nguyen, Z. Zhang, W.O.S. Doherty, Degradation of hydroxycinnamic acid mixtures in aqueous sucrose solutions by the Fenton process, J. Agric Food Chem. 63 (2015) 1582-1592.

[35] S. Jobling, D. Sheahan, A. Osborne, P. Matthiessen, J.P. Sumpter, Inhibition of testicular growth in rainbow trout (Oncorhynchus mykiss) exposed to estrogenic alkylphenolic chemicals, Environ. Toxicol. Chem. 15 (1995) 194202.

[36] S.S. White, L.S. Birnbaum, An overview of the effects of dioxins and dioxin-like compounds on vertebrates, as documented in human and ecological epidemiology, J. Environ. Sci. Health C Environ. Carcinog. Ecotoxicol. Rev. 27 (2009) 197-211. 